\title{
Local Wastes for Synthesis of Different Types of Zeolites
}

\author{
Rawand S. Abdullah ${ }^{1}$ and Kafia M. Shareef ${ }^{2}$ \\ ${ }^{1,2}$ Department of Chemistry, College of Science, University of Salahaddin-Erbil \\ Erbil, Kurdistan, Iraq
}

\begin{abstract}
Locally available wastes were found to provide a good alternative source of highly active silica for the synthesis of zeolites. In the present investigation a collection of barely husk (from Erbil/north of Iraq), colourless glass (fruity glass) and white ceramic glass wastes were used usefully as a renewable sources of silica and alumina for synthesis of four types of zeolites; a suitable procedure was employed to extract silica and alumina from the selected wastes. The detections showed that the barley husk had the largest amount of silica. While the white ceramic glass wastes (laboratory waste) had the largest amount of alumina. Each zeolite sample was prepared starting from a mixture constituted by a source of silica and/or a source of alumina under hydrothermal condition at atmospheric pressure. The studied wastes were converted to zeolite $Y$, zeolite SOD, zeolite A and zeolite AFX. Raw materials and synthesized zeolites were characterized by $x$-ray fluorescence spectroscopy (XRF), X-ray diffraction spectroscopy (XRD) and Infrared spectroscopy (IR).
\end{abstract}

Keywords: Wastes, Silica, Alumina, Zeolite, chemical composition, crystalline.

\section{Introduction}

Zeolite being discovered as "boiling stones" more than 250 years ago[1], zeolites received considerable attention only in the last decades and today turned into essential commercial materials[2].

Zeolites are crystalline Aluminosilicates with a 3-dimensional, open anion framework consisting of oxygen-sharing $\mathrm{TO}_{4}$ tetrahedral, where $\mathrm{T}$ is $\mathrm{Si}$ or Al. Their framework structure contains interconnected voids that are filled with adsorbed molecules or cations. Zeolite micro pore channels have very well-defined diameters so that bulky molecules will be excluded from the internal surface[3, 4]. The general empirical formula is:

$$
\mathrm{M}_{\mathrm{x} / \mathrm{m}} \cdot \mathrm{Al}_{\mathrm{x}} \mathrm{Si}_{2-\mathrm{x}} \mathrm{O}_{4} \cdot \mathrm{n} \mathrm{H}_{2} \mathrm{O}
$$

Where $\mathrm{m}$ is the valence of cations of $\mathrm{M}, \mathrm{n}$ the water content and $0 \leq \mathrm{x} \leq 1$. Several properties account for their commercial use: they are strong adsorbents, they show a very high selectivity and they are excellent solid acid catalysts. Synthetic zeolites are employed in a wide range of industries. For example they are used in the separation of gaseous or liquid compounds. Detergents represent the highest market by volume because of their high ion-exchange capacities. However, the high-added value commercial applications of zeolites are encountered in the petroleum industry[5].

\section{Methodology}

\subsection{Research Goal}

In this study we aim to dropping the accumulation of wastes and using chemical materials in a cheap way. Then using the extracted chemicals in synthesis of very useful materials which we synthesis different types of zeolite where they have many applications.

\subsection{Chemicals}

The chemical materials are used in this research are Sodium Hydroxide NaOH (ALPHA CHEMIKA, Mumbai - 400 002) M.W=40.00 g/mol, Hydrochloric Acid 37\% (RFE, BP, Ph. Eur.) M.W=36.46 g/mol, 
Sulphuric Acid 98\% (GCC) B. No. 3971 M.W=98.07 g/mol, Silica-precipitated acid washed (BDH chemicals Ltd Poole England) M.W=60.09 g/mol, Silver Nitrate 99.8\% (R.P.NORMAPURTMAR) M.W.=169.87 g/mol, Sodium Carbonate 99.5\% (Riedel-deHaën) M.W.=105.99 g/mol, Sodium Silicate (Riedel-deHaën AG SEELZEHANNOVER) M.W=122.06324 g/mol, Sodium Aluminate (Riedel-deHaën SEELZE-HANNOVER) $\mathrm{M} . \mathrm{W} .=87.06704$.

\subsection{Procedures of extraction}

\subsubsection{Extraction of Silica from Barley husk}

The barley seeds collected in Erbil city from Kurdistan region in Iraq then they change to flour in an old factory so there rejected a large amount of barley husk. Weighted $958.17 \mathrm{~g}$ of the barley husk and washed with water and dried at $100^{\circ} \mathrm{C}$ overnight then was treated with $10 \%$ sulfuric acid $\left(\mathrm{H}_{2} \mathrm{SO}_{4}\right)$ for $24 \mathrm{~h}$ for preliminary removing all impurities. The treated barley husk was washed thoroughly with distilled water, dried at $100^{\circ} \mathrm{C}$ and $167.756 \mathrm{~g}$ pyrolyzed in oxygen atmosphere at $580^{\circ} \mathrm{C}$ for $6 \mathrm{~h}$ to obtain white silica powder. The residual white precipitate was dissolved in $\mathrm{NaOH}$ solution to obtain a desired composition of sodium silicate solution[6].

\subsubsection{Extraction of Silica from Colorless Glass and White Ceramic Glass}

Figure 1 represents the flow diagram for production of precipitated amorphous high purity silica from glass (colourless glass or white ceramic glass). The glass was thoroughly washed with distilled water to remove adhering soil and dust and then dried at $110^{\circ} \mathrm{C}$ for $12 \mathrm{~h}$. After that, it was calcined at $800^{\circ} \mathrm{C}$ for $3 \mathrm{~h}$. For producing sodium silicate solution, the reaction mixture of the glass $(25 \mathrm{~g})$ and $250 \mathrm{ml}$ of $\mathrm{NaOH}(2 \mathrm{M})$ solution was stirred for $1 \mathrm{~h}$. The solution was filtered and the residue was washed with $20 \mathrm{ml}$ boiled distilled water. The filtrate and washings were allowed to cool to room temperature and titrated with $2.5 \mathrm{M}$ of $\mathrm{H}_{2} \mathrm{SO}_{4}$ with constant stirring. The $\mathrm{pH}$ of the solution was monitored with $\mathrm{pH}$ meter and titration stopped at $\mathrm{pH} 7$ by $94 \mathrm{ml}$ of the acid. A soft white gel was formed and aged for $6 \mathrm{~h}$. After aging, the slurry was washed with distilled water to remove sodium sulphate and then dried at $110^{\circ} \mathrm{C}$ for $12 \mathrm{~h}$. For removing other mineral contents such as $\mathrm{Al}, \mathrm{Na}$ etc. the dried material was refluxed with $1 \mathrm{M}$ of $\mathrm{HCl}$ at $120^{\circ} \mathrm{C}$ for $2 \mathrm{~h}$ and then washed repeatedly using deionized water to make it acid free. Now, the obtained pure precipitated amorphous silica was dried at $110^{\circ} \mathrm{C}$ for $12 \mathrm{~h}$. The solid residue obtained during filtration was washed with distilled water and dried at $110^{\circ} \mathrm{C}$ for $12 \mathrm{~h}$ [7].

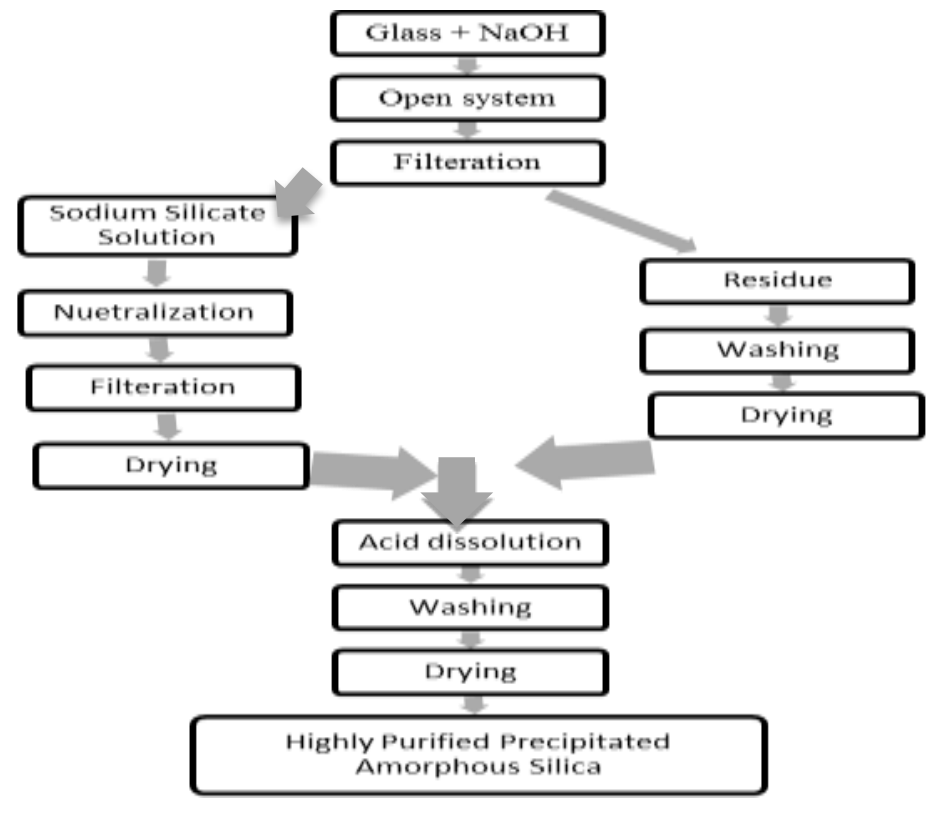

Figure 1 Extraction of Silica from Glass. 


\subsection{Procedure of Zeolites synthesis}

Sodium hydroxide (16g) was added slowly to $40 \mathrm{ml}$ deionized water and stir until clear and homogenous solution appeared for about 5 minutes. The aqueous solution of sodium hydroxide was ready for the preparation of seed gel. 20 milliliter aqueous solution of sodium hydroxide (2M) was added to $7.57 \mathrm{~g}$ sodium aluminate (extracted alumina in zeolite 3) until a homogenous mixture was formed then glass Silica extracted(or silica in zeolite 3) $15.40 \mathrm{~g}$ was added separately to $55 \mathrm{ml}$ sodium hydroxide aqueous (2M) until homogenously mixed. Both of the preparations were heated under vigorous stirring to obtain a homogenous mixture. The sample was aged for $24 \mathrm{~h}$ at room temperature in the Teflon bottle. This combined solution was used as the feed stock gel.

Then the seed gel and feed stock gel mixed slowly in a Teflon beaker, subsequently stirred for $2 \mathrm{~h}$ with the purpose of making it completely homogenized. After the mixed solution insert in a suitable Teflon bottle and begin to aging at room temperature for $24 \mathrm{~h}$. Then the bottle insert in oven at $90^{\circ} \mathrm{C}$ for $22 \mathrm{~h}$ after take out from oven and rapidly open the cap and cooling for an hour at room temperature. Then separate the solid by suction filtration after that the solid pieces washed with hot distilled deionized water until filtrate $\mathrm{pH}$ become 10 . Finally the wet pieces dried in oven at a hundred temperatures for $24 \mathrm{~h}$ the process is shown Figure 2 [6].

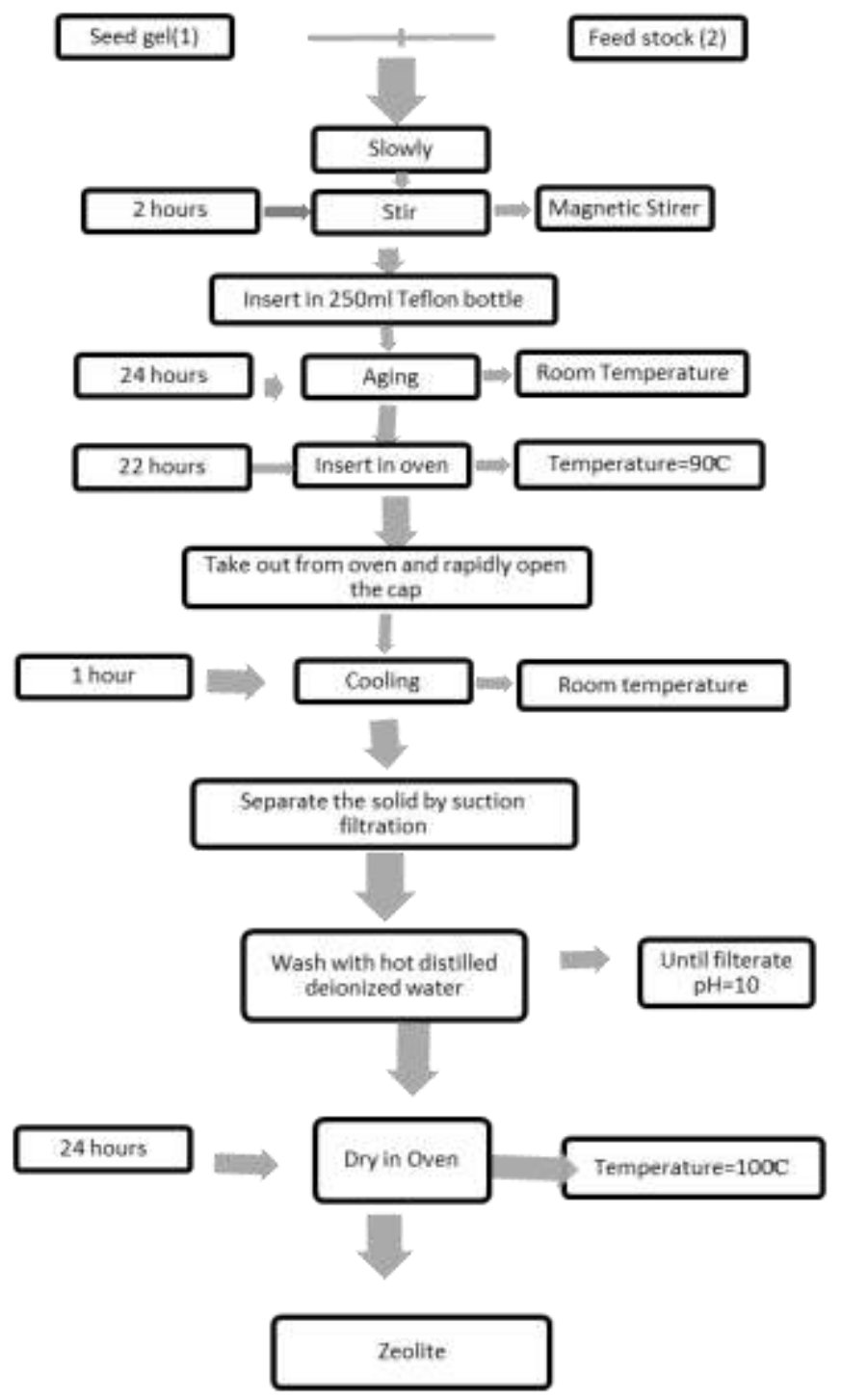

Figure 2 Flow chart for preparation of the Zeolites 


\section{Analyses and Results}

\subsection{IR Characterization of synthesized Zeolites}

Figure ( 3 a-d) show that the bands around 563.58, 667.85, 562.63 and $559.69 \mathrm{~cm}^{-1}$ are related to bending vibration of $\mathrm{SiO}_{4}$ groups or in the vibration modes of the 4-membered rings of silicate chains. The stretching vibration of $\mathrm{SiO}_{4}$ are shifted towards higher frequency indicating that the presence of the internal Si-O $\cdots \mathrm{HO}-\mathrm{Si}$ bonds. The symmetric $\mathrm{TO}_{4}$ stretching region in the spectrum and sharp medium bands around 541 and $472 \mathrm{~cm}^{-1}$. While the peaks of $462.16,446.41,442.17$ and $448.69 \mathrm{~cm}^{-1}$ is bending vibration of $\mathrm{O}-\mathrm{Si}-\mathrm{O}$ occurring in "antiphase"[8]. These absorptions are either due to $\mathrm{TO}_{4}$ bending or the motion of the external linkage of the $\mathrm{AlO}_{4}$ and $\mathrm{SiO}_{4}$ tetrahedral. The weak band at $1480-1380 \mathrm{~cm}^{-1}$ may be affected by the excess cations present in the pores. The broad weak band around $4000-3000 \mathrm{~cm}^{-1}$ is attributed to the stretching vibration of hydrogen group of water molecules present in the pores of the zeolites [4]. The weak and sharp peaks in $1700-1500 \mathrm{~cm}^{-1}$ resulted due to bending vibration of water. The peak at around $1450 \mathrm{~cm}^{-1}$ and the smaller one at $850 \mathrm{~cm}^{-1}$ indicate the presence of $\mathrm{CO}_{3}{ }^{2-}$ anions [9]. The external linkage frequencies occur principally in two regions of the spectrum, 600-500 $\mathrm{cm}^{-1}$. A medium intensity band in the former has been related to the presence of double ring polyhedral in the framework. Thus, all of the zeolite frameworks with D-4 and D-6 rings have a medium band in the $550 \mathrm{~cm}^{-1}$ region. The second main external linkage frequency assigned to a breathing motion of the isolated rings forming pore opening in zeolites. Peak of $563.56 \mathrm{~cm}^{-1}$ is crystallization bond, complex bond, symmetry stretching of Si$\mathrm{O}-\mathrm{Si}$ and bending of $\mathrm{O}-\mathrm{Si}-\mathrm{O}$. The bonds at about $562 \mathrm{~cm}^{-1}$ corresponds to symmetric stretching vibration of 5-member ring in zeolite structure[10]. The sharp peaks at $3471.68,3487.78,3566.69$ and $3479.45 \mathrm{~cm}^{-1}$ is for $\mathrm{O}-\mathrm{H}$ vibration stretching and the sharp small peak at or nearby $1638.12,1653.17,1653.00$ and $1652.80 \mathrm{~cm}^{-1}$ is to $\mathrm{O}-\mathrm{H}$ vibration bending which refers to the presence of water molecules in the zeolite structure of all samples. The band at $2359.86 \mathrm{~cm}^{-1}$ in the figure $3 \mathrm{~d}$ due to present impurities (oxides) in the zeolite 4 . The bands in the range $1000 \mathrm{~cm}^{-1}$ due to silica and alumina of tetrahedral structure thus zeolites 3 and 4 have higher amount than the two others[11].

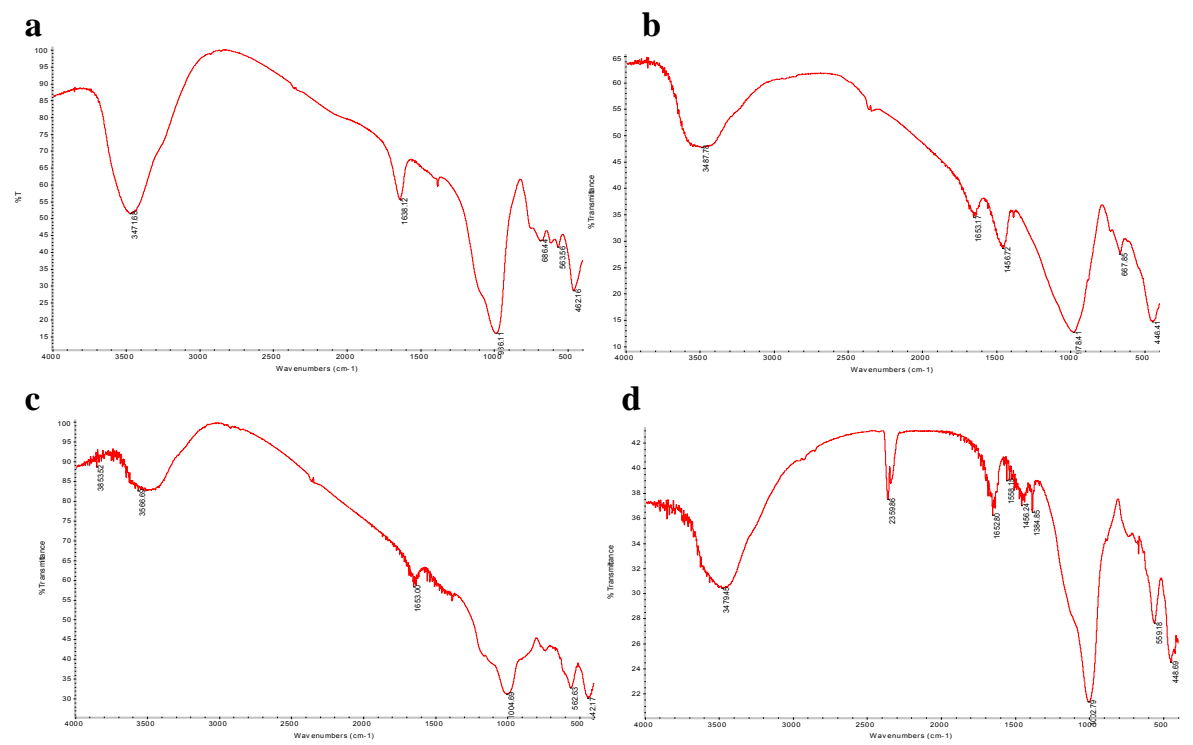

Fig. 3 IR spectra to: a) Zeolite 1 synthesized from barley husk. b) Zeolite 2 synthesized from silica of colourless glass (fruit glass). c) Zeolite 3 synthesized from Alumina of white ceramic glass. d) Zeolite 4 synthesized from Silica of white ceramic glass. 


\subsection{XRF based Chemical composition of the Wastes under study}

In the present investigation three different wastes were used as a source of silica and alumina to synthesize four types of zeolite. Table I represents XRF based the chemical composition in wt. \% of the studied wastes. XRF results showed that barley husk has highest silica content (64.341) which are regarded the best waste among the studied silica sources. However, the White ceramic glass has highest Alumina content (46.246) so it was considered a source of Alumina for zeolites synthesis. The silica content of the studied wastes was in the following order:

Barley husk $>$ colourless glass $>$ white ceramic glass

While the Alumina content of the studied wastes was in the following order:

White ceramic glass $>$ colourless glass $>$ Barley husk

Results are in table I show that the studied wastes contain significant amount of metal and non-metal oxides this may be due to the inefficient calcination process during the extraction. Data in table 1 confirms the result of IR analysis which stated that some raw material is retained during the extraction then after in the polymerization products (synthesized zeolites).

TABLE I: XRF based chemical composition in wt. \% for the studied wastes.

\begin{tabular}{llllllllllll}
\hline \hline Element & $\mathrm{Na}_{2} \mathrm{O}$ & $\mathrm{MgO}$ & $\mathrm{Al}_{2} \mathrm{O}_{3}$ & $\mathrm{SiO}_{2}$ & $\mathrm{P}_{2} \mathrm{O}_{5}$ & $\mathrm{SO}_{3}$ & $\mathrm{~K}_{2} \mathrm{O}$ & $\mathrm{CaO}$ & $\mathrm{MnO}$ & $\mathrm{Fe}_{2} \mathrm{O}_{3}$ & $\mathrm{H}_{2} \mathrm{O}$ \\
\hline Barley Husk & 0.076 & 1.922 & 2.562 & 64.341 & 3.188 & --- & 1.888 & 8.591 & 0.100 & 2.072 & 15.260 \\
Colourless Glass & 0.936 & 1.977 & 3.155 & 62.411 & 0.105 & 0.382 & 0.382 & 12.571 & 0.015 & 0.198 & 18.250 \\
White Ceramic Glass & 0.165 & 0.420 & 46.246 & 34.913 & 0.182 & 0.338 & 0.338 & 2.029 & 7.582 & 0.042 & 1.120 \\
\hline \hline
\end{tabular}

\subsection{XRF Based Chemical Composition of Synthesized Zeolites}

Data in table II represent the XRF based chemical compositions in wt. \% of the synthesized zeolites. The XRF analysis showed a significant variation of the chemical composition in wt. \% of the synthesized zeolites. Silica content of the studied samples was in the following order: Zeolite $2>$ zeolite $1>$ zeolite $4>$ zeolite 3

While Alumina content of the studied samples was in the following order: Zeolite $3>$ zeolite $4>$ zeolite $1>$ zeolite 2. Water content of the studied samples was in the following order: Zeolite $2>$ zeolite $1>$ zeolite $4>$ zeolite 3. It was found that the synthesized zeolite contained other oxides, significant amounts of $\mathrm{CaO}$ together with traces of $\mathrm{Na}_{2} \mathrm{O}, \mathrm{MgO}, \mathrm{P}_{2} \mathrm{O}_{5}, \mathrm{SO}_{3}, \mathrm{~K}_{2} \mathrm{O}, \mathrm{MnO}$ and $\mathrm{Fe}_{2} \mathrm{O}_{3}$.

TABLE II: XRF based chemical composition in wt. \% for the synthesized zeolites:

\begin{tabular}{llllllllllll}
\hline \hline Element & $\mathrm{Na}_{2} \mathrm{O}$ & $\mathrm{MgO}$ & $\mathrm{Al}_{2} \mathrm{O}_{3}$ & $\mathrm{SiO}_{2}$ & $\mathrm{P}_{2} \mathrm{O}_{5}$ & $\mathrm{SO}_{3}$ & $\mathrm{~K}_{2} \mathrm{O}$ & $\mathrm{CaO}$ & $\mathrm{MnO}$ & $\mathrm{Fe}_{2} \mathrm{O}_{3}$ & $\mathrm{H}_{2} \mathrm{O}$ \\
\hline 1 & 0.566 & 0.612 & 26.413 & 29.606 & 0.338 & 0.209 & 0.133 & 7.926 & 0.061 & 1.089 & 33.047 \\
2 & 0.642 & 0.788 & 6.241 & 34.110 & 0.070 & 0.437 & - & 13.148 & 0.019 & 0.240 & 44.305 \\
3 & 0.240 & 0.375 & 45.448 & 25.052 & 0.102 & 0.498 & 1.155 & 7.686 & 0.053 & 1.533 & 17.858 \\
4 & 0.344 & 0.228 & 35.084 & 26.435 & 0.130 & 0.471 & 1.436 & 7.616 & 0.046 & 1.264 & 26.946 \\
\hline \hline
\end{tabular}

\subsubsection{Unit Cell Composition}

From the XRF result the unit cell chemical composition for the studied samples were determined and summarized in table III. Data in table III show the basic components of zeolites unit cells in weight percent of Sodium oxide, Silica, Alumina and Water molecules.

TABLE III: XRF based unit cell chemical composition in wt. \% for the synthesized zeolites:

\begin{tabular}{ll}
\hline \hline Zeolite & Unit cell \\
\hline 1 & $0.566 \mathbf{N a}_{2} \mathbf{O}: 29.606 \mathbf{S i O}_{\mathbf{2}}: 26.413 \mathbf{A l}_{\mathbf{2}} \mathbf{O}_{3}: 33.047 \mathbf{H}_{\mathbf{2}} \mathbf{O}$ \\
2 & $0.642 \mathbf{N a}_{2} \mathbf{O}: 34.110 \mathbf{S i O}_{2}: 6.241 \mathbf{A l}_{\mathbf{2}} \mathbf{O}_{3}: 44.305 \mathbf{H}_{2} \mathbf{O}$ \\
3 & $0.240 \mathbf{N a}_{2} \mathbf{O}: 25.052 \mathbf{S i O}_{2}: 45.448 \mathbf{A l}_{2} \mathbf{O}_{3}: 17.858 \mathbf{H}_{2} \mathbf{O}$ \\
4 & $0.344 \mathbf{N a}_{2} \mathbf{O}: 26.435 \mathbf{S i O}_{\mathbf{2}}: 35.084 \mathbf{A l}_{2} \mathbf{O}_{3}: 26.946 \mathbf{H}_{\mathbf{2}} \mathbf{O}$ \\
\hline \hline
\end{tabular}


Inhomogeneity in the unit cell chemical composition of synthesized zeolites was found this may be due to different types of zeolite prepared during synthesis and to the different sources used for silica and alumina extraction. Although the exact reason for the slightly different chemical composition is not fully understood[12].

\subsubsection{Si to Al ratio and type of Zeolite}

Silicon to Aluminium ratio shows inhomogeneity among the studied samples due to different silica and alumina sources for preparation of zeolite samples and due to the different chemical composition of the prepared samples. According to Si/Al ratio prepared zeolites were identified and their types were summarized in table IV. Zeolite 1 which was synthesized from silica extracted from barley husk the ratio is 1.9761 according to the reference it is zeolite Y. While zeolite 2 the ratio more than nine due to it contains large amount of Silica so it is SOD type. However, zeolite 3 has the Silica to Alumina ratio 0.9717 nearly the same amount of the both elements so it was classified as zeolite A. Finally, zeolite 4 has the ratio more than one thus it is zeolite of type X [13].

\subsection{XRD analyses for the Synthesized Zeolites}

Powder X-ray diffraction (XRD) analysis was performed on the synthesized samples in order to identify or detect different crystalline phases present in the material. Figure (4, a-d) illustrates XRD patterns of four zeolite samples prepared from different wastes as a source of silica and/or alumina. In Figure 4a the first XRD peak is observed at exactly $6.33^{\circ}$ and other peaks are also very sharp indicated crystalline so it is zeolite-Y type[14]. Figure $4 \mathrm{~b}$ we noted that the first peak appear at $14^{\circ}$ of 2 theta angle then the next peaks appear at $31^{\circ}, 47.5^{\circ}$ and $58.5^{\circ}$ so these peaks of zeolite SOD is small (low intensity)[15]. Figure 4c peaks shows we got that is near exact to zeolite A thus we took the range of 2 theta angle of zeolite A from $5^{\circ}$ to $60^{\circ}$. The detected peaks are specially for Zeolite A appear from the range $5^{\circ}$ to $60^{\circ}$ of the X-ray powder pattern diffraction which the last peak of zeolite A appear at $53.5^{\circ}$ angle[15]. Also figure $4 \mathrm{~d}$ shows that peaks of two theta degree exact to zeolite AFX. I was detected the peaks of the zeolite which is first peak at $6.9^{\circ}$ degree of angle diffraction and the last at $30.8^{\circ}$ angle as showed by arrows[16]. The background of a powder XRD pattern can also give an indication about the amorphous materials, whether they are present in the sample or not. It seems that the rest of the samples (zeolites sample b-d) contained large amount of amorphous. It was reported in literature that, a highly crystallized zeolite samples must have quite a flat baseline[17]. Finally, the four samples had a similar XRD with two theta (20) pattern being some amorphous with crystalline phases, indicating the formation of zeolite synthesis was successful.

$\mathbf{a}$

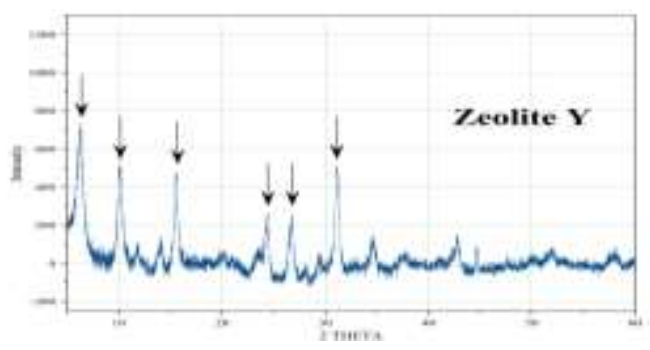

c

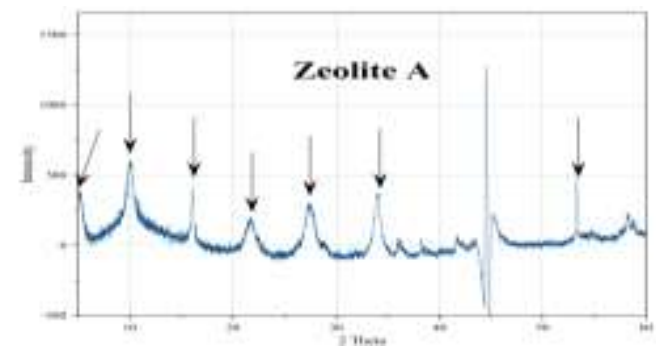

b
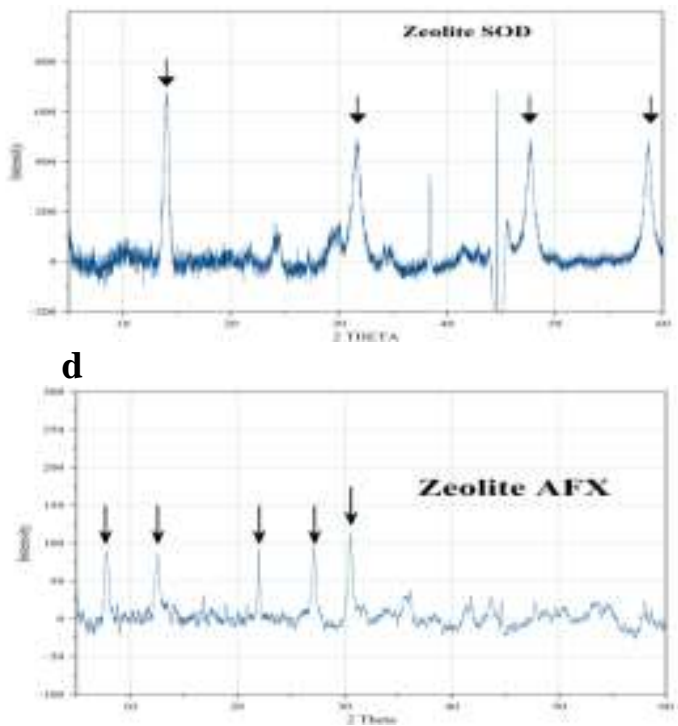

Figure 4 Powder XRD pattern for the synthesized: a) Zeolite 1 prepared from barley husk. b) Zeolite 2 prepared from Silica of colorless glass. c) Zeolite 3 prepared from Alumina of White ceramic Glass. d) Zeolite 4 prepared from Silica of White ceramic Glass. 
The background of a powder pattern can also give an indication about the amorphous materials, whether they are present in the sample or not. As a rule, a highly crystallized zeolite samples must have quite a flat baseline (see figure 5 range two theta from $90^{\circ}$ to $35^{\circ}$ ). Subsequently, zeolite 1 prepared from ceramic glass Silica source has a comparatively highest degree of crystallinity among the four samples. The degree of crystallinity of the studied samples as shown in their XRD patterns in Figure 5 as in the following order:

Zeolite $1>$ zeolite $3>$ zeolite $4>$ zeolite 2

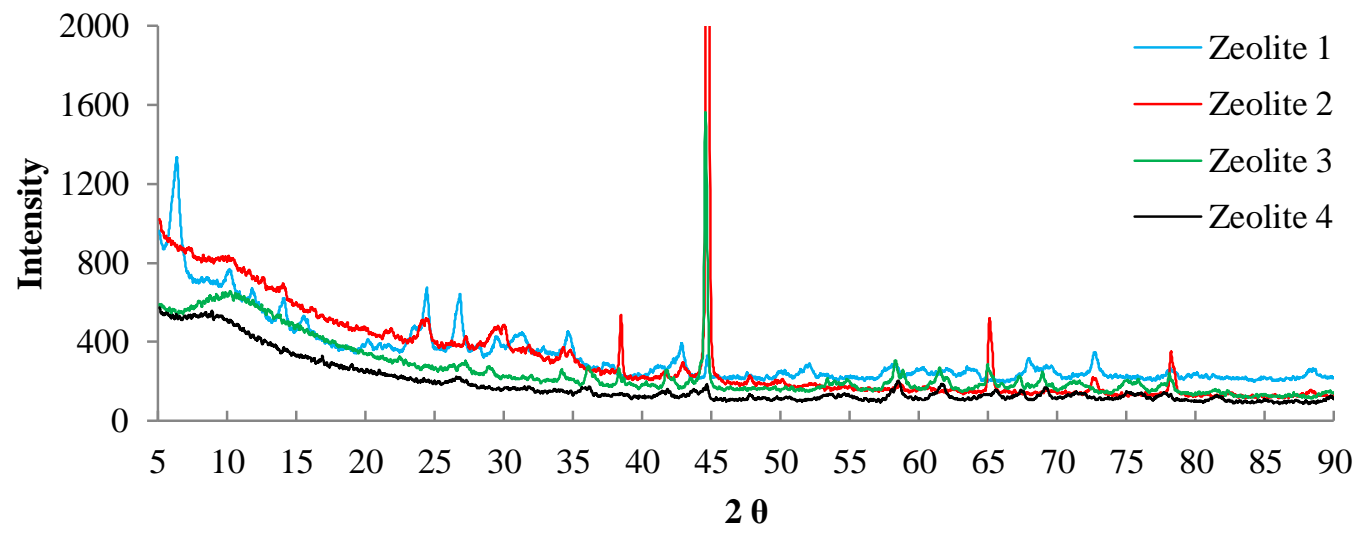

Figure 5 Powder XRD pattern for the synthesized zeolites 1, 2, 3 and 4.

Table IV identifies the types of prepared zeolites from the wastes mentioned in the table. In connection with the structures of the zeolite, the $\mathrm{Si} / \mathrm{Al}$ ratio determines a number of important properties useful for adsorption, catalysis and ion exchange. The trend in these properties as a function of their initial Si/Al ratio for a number of zeolite[13]. The chemical composition, expressed in terms of unit cell contents, has been idealized where necessary for simplicity. The chemical formula is given according to IUPAC recommendations. For each Type Material, the space group and cell parameters listed are taken from the reference cited. In many instances, further refinement of the structure taking into account ordering etc. would yield a lower symmetry. It should also be noted that the space group and other crystallographic data related to the Type Material structure do not necessarily apply to isotypes[18].

TABLE IV: Type of synthesized zeolite predicted from XRF and XRD analysis:

\begin{tabular}{cccc}
\hline \hline Zeolite & Sample Specification & Si /Al ratio & Zeolite type \\
\hline $\mathbf{1}$ & Barley Husk(Silica source) & $\mathbf{1 . 9 7 6 1}$ & $\mathbf{Y}^{[18]}$ \\
$\mathbf{2}$ & Colourless Glass( Silica source) & $\mathbf{9 . 4 5 4 0}$ & $\mathbf{S O D}^{[18,19]}$ \\
$\mathbf{3}$ & White Ceramic Glass (Alumina source) & $\mathbf{0 . 9 7 1 7}$ & $\mathbf{A}^{[19]}$ \\
$\mathbf{4}$ & White Ceramic Glass (Silica source) & $\mathbf{1 . 3 2 8 3}$ & $\mathbf{A F X}^{[18,19]}$ \\
\hline
\end{tabular}

\section{Conclusion}

This research detects that the barley husk has the largest amount of silica than the other wastes while White ceramic Glass has largest amount of Alumina than others however the colorless glass contain large amount of Silica but smaller than the barley husk. These amounts tell us each waste has its special useful. The zeolite syntheses are different because we have different amounts of Silica to Alumina ratios also the extracted samples contain some other of the oxides. The barley husk Silica gave us zeolite type Y, the Colourless glass Silica SOD, the White ceramic Glass Alumina A and White ceramic Glass Silica AFX that is due to the White ceramic Glass waste used as Silica and Alumina sources. I concluded that some wastes can use for preparation of zeolites without using chemical materials after some treatments. 


\section{References}

[1] C. Reyes, "Synthesis of zeolites from geological materials and industrial wastes for potential application in Environmental problems," PhD. thesis, School of Applied Sciences, University of Wolverhampton, P. 10, 2008.

[2] I. Sun. (October 2007), “Zeolite Applications,” p. 59-60, Available: http://www.siberg.com/zeolite.htm.

[3] V. Bekkum and J. C Jacobs, "Introduction to zeolite science and practice”, 2 nd ed, Stud. Surf. Sci. Catal., p. 137, 2001.

[4] T. Tago and T. Masuda, "Zeolite nanocrystals - synthesis and applications", InTech, Faculty of Engineering, Hokkaido University, Hokkaido, Japan, p. 191, 2010.

[5] C. J. Houssin, "Nanopartcles in Zeolite synthesis," PhD. thesis, Inorganic Chemistry and Catalysis, Eindhoven University of Technology, Eindhoven, Netherlands, p. 1, 2003.

[6] M. M. Rahmana and a.W.B.W.N. N. Hasnidab, "Preparation of Zeolite Y Using Local Raw Material Rice Husk as a Silica Source," Journal of Scientific Research, 2009, p. 7.

[7] K. Srivastava, V.D. Niharika Shringi and Ashu Rani, "Pure Silica Extraction from Perlite: Its Characterization and Affecting factors," International Journal of Innovative Research in Science, 2013. p. 7.

[8] K. Byrappa and B.V.S. Kumar, "Characterization of Zeolites by Infrared Spectroscopy,” Asian Journal of Chemistry, 2007. ch. 19, p. 3.

[9] J. Buhl and L.S.a.C.H. Rüscher, "Enclosure of Sodium Tetrahydroborate (NaBH4) in Solidified Aluminosilicate Gels and Microporous Crystalline Solids for Fuel Processing”, licensee InTech, 2012, ch 3, p. 42.

[10] Y. Peña and W. Rondón, "Linde Type a Zeolite and Type Y Faujasite as a Solid-Phase for Lead, Cadmium, Nickel and Cobalt Preconcentration and Determination Using a Flow Injection System Coupled to Flame Atomic Absorption Spectrometry". American Journal of Analytical Chemistry, 2013. p. 11.

[11] D.L. Pavia and G.S.K. Gary M. Lampman, "Introduction to Spectroscopy,” 2001, 3 rd ed. ch. 3 and 6. p. 150 and 309.

[12] G.E. Christidis and H. Papantoni, "Synthesis of FAU Type Zeolite Y from Natural Raw Materials: Hydrothermal SiO2-Sinter and Perlite Glass,” The Open Mineralogy Journal, 2008. p. 5.

[13] S.A.B. Ibrahim, "Synthesis and Characterization of Zeolites from Sodium Aluminum Silicate Solution", Malaysia, 2007: p. 24.

[14] M.M.J. Treacy and J.B. Higgins, "Collection of Simulated XRD Powder Patterns for Zeolites," 4 th ed. ELSEVIR, 2001, p. 586.

[15] J.A.B.L.R.I. Alves and E.R.S.I.P. Dantas, S. B. C.I*; Melo, D. M. A.I; Melo, M. A. F., "Synthesis of high value-added zeolitic materials using glass powder residue as a silica source," Materials Research, 2013. p. 6.

[16] S.R. Vennaa and M.A. Carreon, "Microwave assisted phase transformation of silicoaluminophosphate zeolite crystals Microwave assisted phase transformation of silicoaluminophosphate zeolite crystals," Journal of Materials Chemistry, 2009, p. 3.

[17] N. Katada, T.K. K. Takahara, H.A. Begum and M. Niwa, "Acidic Property of Modified Ultra Stable Y Zeolite: Increase in Catalytic Activity for Alkane Cracking by Treatment with Ethylenediamine-tetraacetic Acid Salt," J. Mole. Catal. A: Chem., 2004, p. 130.

[18] C. Baerlocher, L.B. McCusker, and D.H. Olson, "Atlas of Zeolite framework types," 6 th ed, Structure Commission of the International Zeolite Association-Elsevier, 2007, p. 405.

[19] S.T. Wilson, R.W. Broach, C.S. Blackwell, C.A. Bateman, N.K. McGuire and R.M. Kirchner, "Synthesis, characterization and catalysis of SAPO-56 and MAPSO-56 molecular sieves," Microporous Mesoporous Mat., vol. 28, p. 125-137, 1999.

http://dx.doi.org/10.1016/S1387-1811(98)00293-5 